\title{
Impact of maternal HIV-1 viremia on lymphocyte subsets among HIV-exposed uninfected infants: protective mechanism or immunodeficiency
}

Fatima Kakkar ${ }^{1,2,3^{*}}$, Valerie Lamarre ${ }^{1,2,3}$, Thierry Ducruet ${ }^{4}$, Marc Boucher ${ }^{3,5}$, Silvie Valois ${ }^{3}$, Hugo Soudeyns B, $^{2,7}$ and Normand Lapointe ${ }^{2,3}$

\begin{abstract}
Background: Reports of increased morbidity and mortality from infectious diseases among HIV Exposed Uninfected (HEU) infants have raised concern about a possible underlying immunodeficiency among them. The objective of this study was to assess the immunological profile of HEU infants born to mothers exhibiting different levels of HIV-1 viremia at the time of delivery.

Methods: Study subjects were enrolled in the Centre maternel et infantile sur le SIDA (CMIS) mother-child cohort between 1997 and $2010(n=585)$. Infant CD4 ${ }^{+}$T cell, CD8 ${ }^{+}$T cell and CD19 ${ }^{+}$B cell counts were assessed at 2 and 6 months of age, and compared among HEU infants in groups defined by maternal viral load (VL) at the time of delivery (VL $<50$ copies/ml, VL 50-1000 copies/ml, and VL > 1000 copies/ml) in a multivariable analysis.

Results: At 2 months of age, infants born to mothers with $V L>1000$ copies $/ \mathrm{ml}$ had lower $C D 4^{+} \mathrm{T}$ cell counts compared to those born to mothers with $\mathrm{VL}<50$ copies $/ \mathrm{ml}$ at the time of delivery ( $44.3 \%$ versus $48.3 \%, p=0.007$, and 2884 vs. 2432 cells $/ \mathrm{mm}^{3}, p=0.02$ ). These differences remained significant after adjusting for maternal and infant antiretroviral drug use, gender, race and gestational age, and persisted at 6 months of age. There were no differences in $\mathrm{CD}^{+} \mathrm{T}$ cell count or absolute CD19+ B cell count between groups, though higher CD19+ B cell percentage was seen among infants born to mothers with $\mathrm{VL}>1000$ copies $/ \mathrm{ml}$.

Conclusions: These results suggest that exposure to high levels of HIV-1 viremia in utero, even in the absence of perinatal transmission, may affect the infant's developing immune system. While further work needs to be done to confirm these findings, they reinforce the need for optimal treatment of HIV infected pregnant women, and careful follow-up of HEU infants.
\end{abstract}

Keywords: Mother-to-child HIV human immunodeficiency virus transmission, Antiretroviral drugs, Viral load, Immune suppression, Immune system

\section{Background}

The development and successful implementation of prevention of mother-to-child transmission (PMTCT) programs has reduced the risk of perinatal transmission of HIV-1 from $25-30 \%$ to less than $1 \%$ [1,2]. In Canada, as in many parts of the developed world, HIV-exposed uninfected (HEU) infants significantly outnumber those who

\footnotetext{
* Correspondence: fatima.kakkar@umontreal.ca

'Division of Infectious Diseases, CHU Sainte-Justine, 3175 Côte

Sainte-Catherine, Montreal, Quebec H3T 1C5, Canada

2Department of Pediatrics, Faculty of Medicine, Université de Montréal,

Montreal, Canada

Full list of author information is available at the end of the article
}

are infected [3]. However, despite successfully averting HIV-1 infection, there is emerging concern about the health of HEU infants [4]. Reports from South Africa, the Caribbean, South-East Asia and Europe have found increased morbidity and mortality from infectious diseases among HEU infants [5-9]. HEU infants have been found to have a higher incidence of neonatal infections, neonatal sepsis, respiratory illness, acute gastroenteritis, hospitalization, and post-operative complications compared to the general population [10-15], and compared to HIVunexposed uninfected controls $[16,17]$. Perhaps most concerning are reports of pneumonia caused by Pneumocystis 
jiroveci, normally considered to be an HIV-associated opportunistic infection, among HEU infants [18-20].

While the cause of this increased morbidity and mortality from infectious diseases among HEU infants is likely to be multifactorial, encompassing environmental, maternal, and health systems factors, the increased burden of infections seen among them raises the question of whether a relative state of immunodeficiency may contribute to their increased susceptibility to disease [21]. A number of studies to date have shown evidence of various immunological abnormalities among HEU children. The most consistent findings have been markers of increased immune activation and reduced total and naive $\mathrm{CD}^{+}{ }^{+} \mathrm{T}$ cell counts in HEU newborns [22-26]. It is hypothesized that these immunological changes may result from a combination of factors whereby the in utero environment of HIV infected mothers uniquely shapes their infant's immune system. Previous studies have shown an association between maternal antiretroviral (ART) drug use and lower infant CD4 counts and thymic CD4 output [27,28], maternal CD4 count and infant CD4 count $[29,30]$, and maternal recreational drug use and lower infant CD4 counts [31], though few have studied the impact of maternal HIV-1 viremia on infant immunological parameters. However, there is increasing evidence across a range of infectious diseases (viral, bacterial and parasitic) to suggest that chronic maternal infections during pregnancy can affect an infant's immune response to future infections, independently of the vertical transmission of pathogens [32]. In utero sensitization of the fetal immune system to maternal pathogens is thought to lead to altered cytokine, proliferative, and antibody responses to these pathogens in the infant [33-35]. There is evidence that HEU infants are exposed to HIV-1 in utero; circulating HIV-1 proteins and/or immune complexes have been shown to induce strong HIV-specific $\mathrm{T}$ helper and cytotoxic $\mathrm{T}$ cell responses in HEU newborns, when these infants clearly are uninfected [36-39].

Given the reports of increased morbidity and mortality from infectious diseases among HEU infants, and our limited understanding on the nature and cause of immune abnormalities in these children, the objective of the present study was to test the hypothesis that is in utero exposure to high levels of $\mathrm{HIV}-1$ viremia may drive the immunological changes seen among HEU, in the absence of acute infection.

\section{Methods}

\section{Study population}

The Centre maternel et infantile sur le SIDA (CMIS) Mother-Child Cohort was established in 1988 to prospectively follow all pregnant HIV-infected women and their newborns presenting to Centre hospitalier universitaire (CHU) Sainte-Justine, a tertiary referral center in Montreal, Canada. HIV infected women were treated by a mutlidisplinary obstetrics-infectious diseases team on site, and HIV-1 plasma RNA levels at the time of delivery were measured in real time using the Versant HIV-1 RNA assay (Bayer, Pittsburg), with a detection threshold of $2.70 \log 10$ (500) HIV-1 RNA copies/ml (version 2.0, 1997-2000), or $1.70 \log 10$ (50) HIV RNA copies/ml plasma (version 3.0, 2000-2010).

HIV exposed infants were followed closely in the first 2 years of life to determine their HIV status and to monitor for the effects of in utero and post-natal exposure to ART. HIV infection status in infants was determined using 4 negative HIV-1 DNA PCR tests (2 weeks, 1 month, 2 month and 4 months of life) (Roche Amplicor), and the absence of HIV-1 antibodies by ELISA at or after 18 months of age. All infants in the cohort were exclusively formula fed, and received 6 weeks of ART for prevention of mother-to-child transmission as soon as it became available. This resulted in different neonatal treatment regimens over time. From 1994-1997, infants at our center received AZT alone, from 1998-1999 AZT in combination with 3TC, and from 1999-2007, AZT, 3TC and Nelfinavir. Following the recall of Nelfinavir in 2007, the neonatal regimen changed again from 2007-2010 to a combination of AZT and 3TC. Clinical and laboratory monitoring included complete physical exam at every visit, routine haematology and biochemistry tests until 18 months of age, and numeration of lymphocyte subsets $\left(\mathrm{CD}^{+} \mathrm{T}\right.$ cells, $\mathrm{CD}^{+} \mathrm{T}$ cells, CD19 ${ }^{+} \mathrm{B}$ cells) by flow cytometry at 2 and 6 months of age. After 2 years of age, children were offered annual pediatric follow up until age 5 , and every 2 years thereafter. Demographic and laboratory data were collected at every visit and entered into the CMIS database. Informed consent was sought and obtained from all participants to the CMIS Cohort. This protocol was reviewed and approved by the Ethics Review Board of CHU Sainte-Justine, Montreal, Canada, where the study was conducted.

All HEU infants born between 1997 and 2010 were eligible for the study, though infants for whom immunological data was not available at the specified ages of 2 and 6 months (due to visits outside of the routine schedule) were excluded from the analysis, given the large variability in infant lymphocyte subsets over the first few months of life. Out of a total 585 mother-infant pairs, 424 motherinfant pairs were assessed at 2 months of age and 380 at 6 months of age (Figure 1).

\section{Statistical analysis}

Descriptive statistics were used to characterize the study population. For continuous variables, means and ranges were reported. For discrete variables, percentages were reported. For the primary analysis, infants were then categorized into 3 groups based on maternal VL closest to delivery, i.e. $>1,000,50-1,000$, and $<50 \mathrm{HIV}-1$ RNA 


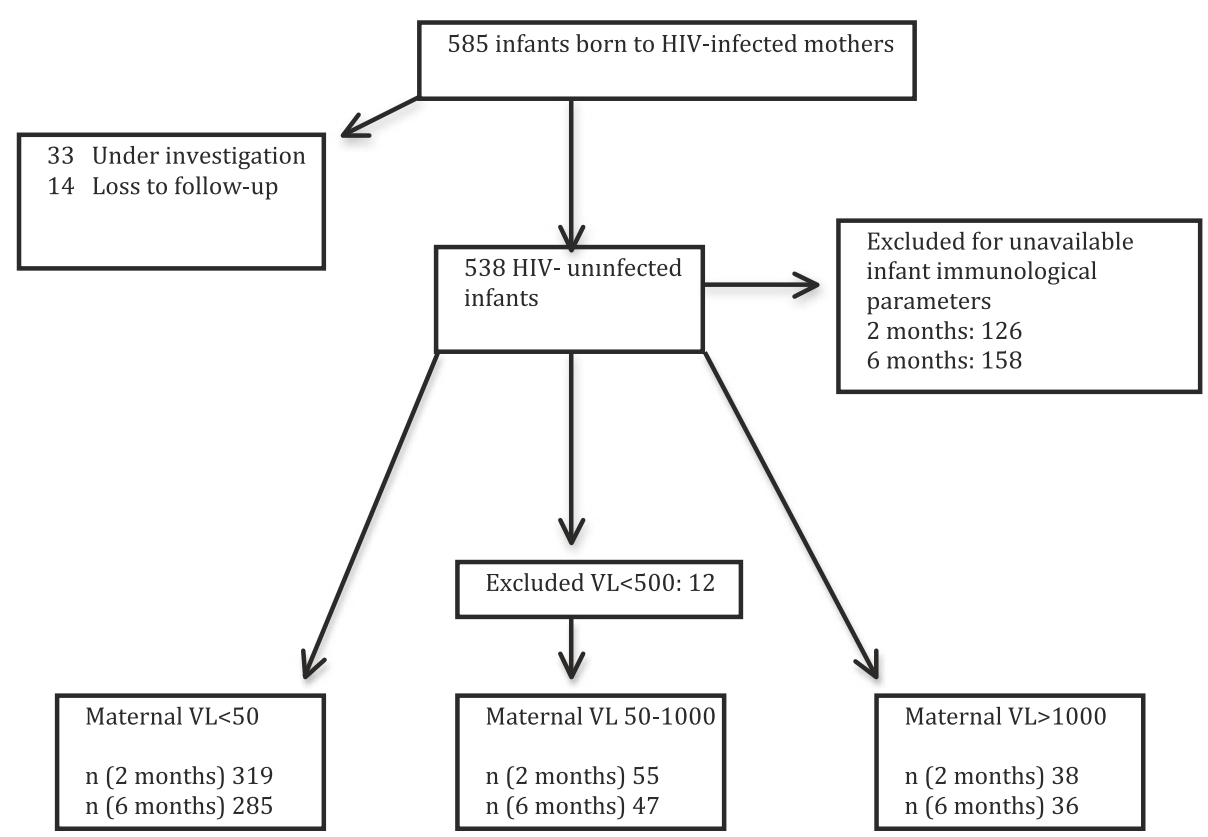

Figure 1 Participant enrollment and flow diagram for mother-infant pairs included in the analysis at 2 and 6 months of age.

copies/ml plasma. Given the changes in the sensitivity of VL testing over time, infants born to mothers with VL $<500$ HIV-1 RNA copies/ml plasma $(\mathrm{n}=12)$, while considered undetectable at the time, were removed from the analysis given that we could not be certain about their true $\mathrm{VL}$, and in order to ensure heterogeneity within strata. Infant $\mathrm{CD} 4^{+} \mathrm{T}$ cell, $\mathrm{CD} 8^{+} \mathrm{T}$ cell, and $\mathrm{CD} 19^{+} \mathrm{B}$ cell counts (relative and absolute) were then compared among infants in each of these 3 maternal VL strata using one-way analysis of variance. Multivariable analysis of variance was conducted to adjust for confounders identified a priori from published literature [22-26], including maternal $\mathrm{CD}_{4}^{+} \mathrm{T}$ cell counts, exposure to ART (mother and infant), gestational age, gender and race. The different models used in the final analysis and the significance of each variable included are presented as supplementary information in an Additional file 1: Table S1. All statistical tests were 2-sided and statistical significance threshold was set at $\mathrm{p}<0.05$. All data were analyzed using SAS version 9.2 (SAS Institute, Cary, NC).

\section{Results}

\section{Maternal characteristics}

Among HIV-infected mothers, $12.3 \%$ received no ART, $13.2 \%$ were treated with zidovudine (AZT) monotherapy, $8.4 \%$ with double combination therapy (AZT and lamivudine [3TC]), and $66.2 \%$ received combination ART (cART) during pregnancy. Median maternal age was 31 years $(\mathrm{IQ}=$ $27-34$ years). $71.9 \%$ of mothers were categorized as not immunosuppressed at delivery $\left(\mathrm{CD} 4>350\right.$ cells $\left./ \mathrm{mm}^{3}\right)$, while $19.7 \%$ were moderately immunosuppressed $(C D 4=200$
350 cells $/ \mathrm{mm}^{3}$ ) and $8.4 \%$ were severely immunosuppressed $\left(\mathrm{CD} 4<200\right.$ cells $\left./ \mathrm{mm}^{3}\right)$. HIV-1 VL at delivery was undetectable ( $<50$ HIV-1 RNA copies/ml plasma) in $77.7 \%$ of mothers, $11.7 \%$ had a VL between 50 and 1,000 HIV-1 copies/ml plasma, and 10.4\% had VL $>1,000$ HIV-1 RNA copies/ml plasma. Among those with VL $>1000$ copies/ml, median VL was 6352 (IQR 2600-10433 copies/ml). Maternal characteristics according to delivery viral load are summarized in Table 1.

\section{Infant characteristics}

$46.7 \%$ of infants were female and $53.3 \%$ were male. $29.7 \%$ were identified as Caucasian, $63.2 \%$ were black, $4.6 \%$ were mixed, and $2.5 \%$ were classified as other. When grouped by region of origin, $33.1 \%$ of infants were classified as African, $31.5 \%$ were Haitian, $28.4 \%$ Canadian, and the remaining $7.0 \%$ mixed-Canadian or other. With respect to ART given to newborns for PMTCT, $12.9 \%$ received no ART, $11.5 \%$ received AZT monotherapy, 28.7\% received AZT and 3TC, and $46.9 \%$ received 3 or more antiretroviral agents.

\section{Lymphocyte subsets Infant $\mathrm{CD} 4^{+} T$ cell counts}

There was a significant difference in $\mathrm{CD} 4^{+} \mathrm{T}$ cell counts at both 2 and 6 months of age among infants born to mothers with HIV-1 VL $>1,000$ vs. $<50$ HIV-1 RNA copies/ml plasma (Tables 2 and 3). At 2 months of age, infants born to mothers with undetectable VL had higher CD4 counts compared to those with $\mathrm{VL}>1,000$ HIV-1 RNA copies/ml plasma ( $48.3 \%$ vs. $44.3 \%$, $\mathrm{p}=$ 0.007 and 2884 vs. 2432 cells $\left./ \mathrm{mm}^{3}, \mathrm{p}=0.02\right)$. These 
Table 1 Maternal characteristics according to delivery viral load

\begin{tabular}{|c|c|c|c|}
\hline Maternal group & Viral load <50 copies/ml & Viral load 50-1000 copies/ml & Viral load $>1000$ copies $/ \mathrm{ml}$ \\
\hline Median viral load (IQR) & NA & $244(105-506)$ & $6252(2600-10433)$ \\
\hline \multicolumn{4}{|l|}{ Maternal age } \\
\hline (Mean, SD) & $31.5(5.5)$ & $29.8(5.3)$ & $30.8(5.2)$ \\
\hline \multicolumn{4}{|l|}{ Delivery CD4 count ( $\mathrm{n}, \%)$} \\
\hline$>350$ & $276(80.5)$ & $34(63.0)$ & $27(58.7)$ \\
\hline $200-350$ & 49 (14.3) & $9(16.7)$ & $8(17.4)$ \\
\hline$<200$ & $18(2.2)$ & $11(20.4)$ & $11(23.9)$ \\
\hline \multicolumn{4}{|l|}{ Gestational age } \\
\hline (Mean, SD) & $38.5(2.2)$ & $38.1(1.9)$ & $37.7(2.7)$ \\
\hline \multicolumn{4}{|l|}{ Pre-term (n, \%) } \\
\hline (<37 weeks) & $50(14.1)$ & $9(16.4)$ & $9(18.8)$ \\
\hline \multicolumn{4}{|l|}{ ART regimen } \\
\hline None & $3(0.9)$ & $2(3.7)$ & $6(12.5)$ \\
\hline AZT & $5(1.4)$ & $3(5.6)$ & $7(14.6)$ \\
\hline $\mathrm{AZT} / 3 \mathrm{TC}$ & $27(7.6)$ & $6(11.1)$ & $4(8.3)$ \\
\hline CART & $319(90.1)$ & $43(79.6)$ & $21(64.6)$ \\
\hline
\end{tabular}

differences persisted at 6 months of age (46.1\% vs. 42.1\%, $\mathrm{p}=0.009$, and 2887 vs. 2271 cells $\left./ \mathrm{mm}^{3}, \mathrm{p}=0.002\right)$, and remained statistically significant after adjusting for gestational age, race, gender, maternal and infant ART exposure, and maternal $\mathrm{CD}^{+} \mathrm{T}$ cell counts at the time of delivery.

\section{Infant $C D 19^{+} B$ cell counts}

There was a significant difference in the percentage of CD $19^{+} \mathrm{B}$ cells among infants born to mothers with HIV$1 \mathrm{VL}>1,000$ vs. $<50$ RNA copies/ml plasma at 2 and 6 months of age, with higher $\mathrm{CD} 19^{+} \mathrm{B}$ cell percentages among infants born to mothers with higher VL $(>1,000$ copies) compared to those whose mothers were undetectable at the time of delivery $(28.7 \%$ vs. $24.5 \%, \mathrm{p}=$ 0.003 , and $30.8 \%$ vs. $26.6 \%, \mathrm{p}=0.008$, respectively).

This difference remained significant after adjusting for gestational age, race, gender, maternal and infant ART exposure, and maternal $\mathrm{CD}^{+} \mathrm{T}$ cell counts at the time of delivery ( $p=0.01$ and $p<0.001$, respectively). The differences in absolute CD19 count at 2 and 6 months of age (1479 vs. 1446 cells $/ \mathrm{mm}^{3}$ and 1528 vs. 1687 cells $/ \mathrm{mm}^{3}$ ) were not statistically significant $(\mathrm{p}=0.79$ and $\mathrm{p}=0.27$, respectively), both in the unadjusted and adjusted analysis.

\section{Infant $C D 8^{+} T$ cell counts}

There was no significant difference in $\mathrm{CD}^{+} \mathrm{T}$ cell count (absolute or percentage) among infants born to mothers with HIV-1 VL > 1000 vs. $<50$ RNA copies/ml plasma at 2 months of age $(15.5 \%$ vs. $15.4 \%, \mathrm{p}=0.90$ and 849 vs. 931 , $\mathrm{p}=0.26)$ nor at 6 months of age (15.2 vs. $15.2, \mathrm{p}=0.99$ and 828 vs 961 cells $\left./ \mathrm{mm}^{3}, \mathrm{p}=0.10\right)$, both unadjusted and adjusted.

\section{Discussion}

This study of HEU infants in Canada revealed differences in infant $\mathrm{CD}^{+} \mathrm{T}$ cell counts as a function of maternal HIV-1 VL measured at the time of delivery. Decreased $\mathrm{CD}^{+}{ }^{+} \mathrm{T}$ counts (relative and absolute) were observed at 2 and 6 months of age in infants born to mothers with a $\mathrm{VL}>1000$ copies/ml at the time of delivery, when compared to infants born to mothers with undetectable viral load (<50 copies/ml). Our findings are consistent with a recent study from Malawi [40] which also found decreased CD4\% at one month of age among HEU infants compared to unexposed uninfected controls, with CD4 values (mean 44\% IQR 39-50) similar to those reported in the present study among 2 month old infants born to mothers with $\mathrm{VL}>1000$ copies/ml (mean 44.4, 95\% CI 41.3-47.5). Though the specific mechanisms behind this association have yet to be understood, it has been shown that HIVinfected, ART-treated women have greatly increased placental production of inflammatory cytokines, tumor necrosis factor alpha (TNF- $\alpha$ ), and interleukin 8 (IL-8) compared to uninfected women $[41,42]$, and mothers with high VL have been shown to generate higher levels of the pro-inflammatory cytokines INF- $\delta$ and TNF- $\alpha$ [43]. This pro-inflammatory, immune activated intra-uterine state is likely be increased in women with poorly controlled HIV1 viremia, and could potentially be the driving force behind the differences in CD4 count seen in this study among the infants born to mothers defined by extremes of maternal viral control (<50 vs. $>1000$ copies $/ \mathrm{ml}$ ).

The significance of the changes in CD19+ B cell counts is not clear. Infants born to mothers with $\mathrm{VL}>$ 1000 copies $/ \mathrm{ml}$ at the time of delivery had an increased 
Table 2 Infant CD4, CD19 and CD8 parameters at 2 months of age

\begin{tabular}{|c|c|c|c|c|c|c|c|c|c|c|c|c|c|}
\hline Maternal viral load & & $\begin{array}{l}\text { CD4 } \\
\text { (mean, 95\% Cl) }\end{array}$ & $\mathbf{p}^{+}$ & $\begin{array}{l}\text { Adjusted CD4 } \\
\text { (mean, 95\% CI) }\end{array}$ & $p^{\neq}$ & $\begin{array}{l}\text { CD19 } \\
\text { (mean, 95\% Cl) }\end{array}$ & $p^{\dagger}$ & $\begin{array}{l}\text { Adjusted CD19 } \\
\text { (mean, 95\% CI) }\end{array}$ & $p^{\neq}$ & $\begin{array}{l}\text { CD8 } \\
\text { (mean, 95\% CI) }\end{array}$ & $p^{+}$ & $\begin{array}{l}\text { Adjusted CD8 } \\
\text { (mean, 95\% Cl) }\end{array}$ & $\mathrm{P}^{ \pm}$ \\
\hline \multirow[t]{2}{*}{$>1000$} & Relative* & $44.3(41.5-47.0)$ & 0.007 & $43.5(40.6-46.3)$ & 0.001 & $28.7(26.1-31.4)$ & 0.003 & $29.3(26.4-32.2)$ & 0.001 & $15.5(14.0-17.1)$ & 0.90 & $16.0(14.4-17.6)$ & 0.58 \\
\hline & Absolute ${ }^{* *}$ & $2432(2072-2792)$ & 0.02 & 2395 (2009-2781) & 0.022 & 1479 (1255-1703) & 0.79 & $1510(1272-1747)$ & 0.49 & 849 (713-985) & 0.26 & $868(721-1015)$ & 0.94 \\
\hline \multirow[t]{2}{*}{$50-1000$} & Relative & 48.7 (46.2-51.3) & 0.74 & $48.6(46.1-51.0)$ & 0.99 & $23.8(21.3-26.4)$ & 0.65 & $24.2(21.7-26.7)$ & 0.96 & $15.8(14.4-17.2)$ & 0.68 & $15.6(14.2-17.0)$ & 0.73 \\
\hline & Absolute & $2872(2533-3210)$ & 0.94 & 2888 (2548-3229) & 0.96 & 1375 (1165-1585) & 0.53 & 1416 (1206-1625) & 0.57 & 952 (824-1079) & 0.77 & 947 (817-1077) & 0.80 \\
\hline \multirow[t]{2}{*}{$<50$} & Relative & $48.3(47.3-49.2)$ & \multirow{2}{*}{ Ref } & $48.5(47.6-49.5)$ & \multirow{2}{*}{ Ref } & $24.5(23.5-25.4)$ & \multirow{2}{*}{ Ref } & $24.1 \quad(23.2-25.1)$ & \multirow{2}{*}{ Ref } & $15.4(14.9-16.0)$ & \multirow[t]{2}{*}{ Ref } & $15.5(15.0-16.1)$ & \multirow{2}{*}{ Ref } \\
\hline & Absolute & 2884 (2759-3010) & & 2878 (2751-3005) & & $1446(1369-1523)$ & & 1419 (1342-1497) & & 931 (884-979) & & 930 (882-979) & \\
\hline
\end{tabular}

*Relative counts are reported as percentages.

${ }^{* *}$ Absolute counts are reported as cells $/ \mathrm{mm}^{3}$.
${ }^{+}$Comparing means in group $\mathrm{VL}>1000$ and $\mathrm{VL} 50-1000$ to $\mathrm{VL}<50$ (reference group) using sum of least squares.

${ }^{\ddagger}$ Adjusted for maternal CD4, maternal ART use, infant ART use, gender, gestational age and race in a multivariable analysis of variance. 
Table 3 Infant CD4, CD19 and CD8 parameters at 6 months of age

\begin{tabular}{|c|c|c|c|c|c|c|c|c|c|c|c|c|c|}
\hline Maternal viral load & & $\begin{array}{l}\text { CD4 } \\
\text { (mean, 95\% Cl) }\end{array}$ & $p^{\dagger}$ & $\begin{array}{l}\text { Adjusted CD4 } \\
\text { (mean, 95\% CI) }\end{array}$ & $p^{\neq}$ & $\begin{array}{l}\text { CD19 } \\
\text { (mean, 95\% CI) }\end{array}$ & $p^{+}$ & $\begin{array}{l}\text { Adjusted CD19 } \\
\text { (mean, 95\% CI) }\end{array}$ & $p^{\neq}$ & $\begin{array}{l}\text { CD8 } \\
\text { (mean, 95\% CI) }\end{array}$ & $p^{\dagger}$ & $\begin{array}{l}\text { Adjusted CD8 } \\
\text { (mean, } 95 \% \mathrm{Cl} \text { ) }\end{array}$ & $\mathrm{P}^{\ddagger}$ \\
\hline \multirow[t]{2}{*}{$>1000$} & Relative* & $42.1(39.3-44.9)$ & 0.009 & $40.1(37.1-43.1)$ & $<0.001$ & 30.8 (27.9-33.7) & 0.008 & $32.9(29.8-36.1)$ & $<0.001$ & $15.2(13.6-16.8)$ & 0.99 & $14.9(13.2-16.6)$ & 0.73 \\
\hline & Absolute** & 2271 (1907-2635) & 0.002 & $2290(1893-2687)$ & 0.022 & $1528(1261-1794)$ & 0.27 & $1712(1420-2003)$ & 0.73 & $828(680-977$ & 0.10 & $853(690-1016)$ & 0.95 \\
\hline \multirow[t]{2}{*}{ 50-1000 } & Relative & $47.0(44.5-49.4)$ & 0.52 & $46.8(44.3-49.2)$ & 0.78 & 27.0 (24.5-29.6) & 0.75 & $27.8(25.2-30.4)$ & 0.27 & $15.8(14.4-17.1)$ & 0.43 & $15.3(13.9-16.7)$ & 0.24 \\
\hline & Absolute & $2861(2540-3181)$ & 0.88 & $2876(2550-3202)$ & 0.96 & $1727(1492-1961)$ & 0.76 & 1788 (1549-2027) & 0.32 & 937 (806-1068) & 0.74 & 926 (792-1060) & 0.68 \\
\hline \multirow[t]{2}{*}{$<50$} & Relative & $46.1(45.1-47.1)$ & \multirow{2}{*}{ Ref } & $46.4(45.4-47.4)$ & \multirow{2}{*}{ Ref } & $26.6(25.5-27.6)$ & \multirow{2}{*}{ Ref } & $26.2(25.2-27.3)$ & \multirow{2}{*}{ Ref } & $15.2(14.6-15.7)$ & \multirow{2}{*}{ Ref } & $15.3(14.7-15.8)$ & \multirow{2}{*}{ Ref } \\
\hline & Absolute & 2887 (2756-3017) & & $2878(2747-3010)$ & & 1687 (1592-1783) & & $1656(1559-1752)$ & & 961 (908-1014) & & $957(903-1011)$ & \\
\hline
\end{tabular}

*Relative counts are reported as percentages.

**Absolute counts are reported as cells $/ \mathrm{mm}^{3}$.

${ }^{+}$Comparing means in group VL $>1000$ and $V L 50-1000$ to $V L<50$ (reference group) using sum of least squares.

${ }^{\ddagger}$ Adjusted for maternal CD4, maternal ART use, infant ART use, gender, gestational age and race in a multivariable analysis of variance. 
$\mathrm{CD} 19^{+} \mathrm{B}$ cell percentage, though no change was seen in their absolute CD19+ B cell count. To date, B cell function among HEU infants is not well understood. Some studies have shown a more robust antibody response to vaccines among HEU infants as compared to unexposed, uninfected controls $[44,45]$. When compared to Hepatitis $\mathrm{C}$ exposed infants, HEU infants have been shown to have lower levels of transferred maternal antibodies at birth and significantly higher total immunoglobulin levels until 2 years of age [46], and it is thought that reduced maternal antibody interference with vaccines may contribute to a stronger vaccine response. However, others studies have reported decreased neutralizingantibody titres to the oral poliovirus vaccine [47] and diminished response to the Hepatitis $B$ vaccine among HEU infants [48]. Given the uncertainty surrounding B cell function among HEU, it is not clear if our findings of decreased CD19\% in the absence of changes to absolute CD19 count are suggestive of an altered overall immunological profile in response to aggravated HIV exposure, or simply represent an isolated finding.

Our study is limited by our ability to control for other confounders that are both known and hypothesized to affect infant immune status, including malnutrition, recreational exposure to hard drugs, and cytomegalovirus co-infection status [21]. While all women in our cohort received identical treatment by the same team of caregivers under a system of universal healthcare access (including social welfare benefits), we were unable to adjust for individual differences in overall health, nutritional, socioeconomic and social status. Most importantly, the clinical implications of these subtle differences in $\mathrm{CD}^{+} \mathrm{T}$ cell counts among HEU infants are not clear. Extrapolating from studies in endemic settings, they may translate into an increased susceptibility to infectious diseases. HEU infants born to severely immunocompromised mothers $\left(C D 4<200\right.$ cells $\left./ \mathrm{mm}^{3}\right)$ in a South African cohort were found to be at higher risk of developing early- and lateonset sepsis than those born to mothers with CD4 > 350 cells $/ \mathrm{mm}^{3}$ [49]. Data from the Ban trial in Malawi further demonstrated that low total white blood cell counts at birth are a significant predictor of serious morbidity and mortality among HEU infants [50]. The small differences in CD4 count seen in the present study may further be compounded by functional immune abnormalities, something that was not specifically examined.

\section{Conclusion}

In conclusion, the results of this study may contribute to an understanding of the immune system of HEU infants, and provide insight into the causes of the increased morbidity and mortality from infectious diseases seen among HEU infants in HIV-endemic settings. Mothers with higher levels of HIV-1 viremia are likely to be sicker, experience faster disease progression, and be less able to care for their infants. These infants, though uninfected, possibly take 2 hits: a relative state of immunodeficiency marked by decreased $\mathrm{CD}^{+}{ }^{+} \mathrm{T}$ cell count and decreased placental transfer of protective maternal antibodies, and increased exposure to infectious diseases from sicker parents. While in well-resourced settings this may have little clinical impact given access to treatment and care, in resource-limited settings, susceptibility to even mild, self-limited diseases such as upper respiratory tract infections or gastroenteritis could lead to significant infant morbidity and mortality. In short, these results reinforce the need for optimal treatment of all HIV-infected pregnant women, both to prevent perinatal HIV transmission, and to limit possible adverse events resulting from in utero exposure to high level HIV viremia. Further studies are needed to detail the immunological response among these infants, and to determine any functional immune abnormalities.

\section{Additional file}

Additional file 1: Table S1. Multiple linear regression models.

\section{Abbreviations}

3TC: Lamivudine; ART: Antiretroviral therapy; AZT: Zidovudine; CHU: Centre hospitalier universitaire; CMIS: Centre maternel et infantile sur le SIDA: HEU: HIV-exposed uninfected; HIV-1: Human immunodeficiency virus type 1; PMTCT: Prevention of mother to child transmission.

\section{Competing interests}

The authors declare that they have no competing interests.

\section{Authors' contributions}

FK conceptualized the study, participated in the statistical analysis, and drafted the final manuscript. VL contributed to the study design and writing of the final manuscript. TD conducted the statistical analysis. SV collected and did a preliminary analysis of the data. HS participated in the design of the study, interpretation of findings, and helped draft the final manuscript. $\mathrm{NL}$ established and was responsible for the management of the cohort, conducted the immunological analysis, and contributed to the final manuscript. All authors read and approved the final manuscript.

\section{Acknowledgements}

We thank the children and families for their participation in CMIS cohort, the CMIS study team, and all members of the CMIS clinical team for the ongoing care provided to patients. This work was supported in part by grants from Réseau SIDA et maladies infectieuses of the Fonds de la recherche du Québec-santé (FRQ-S) to HS, VL, and NL, and scholarship support from the Foundation Sainte-Justine and Harvard School of Public Health to FK.

\section{Funding source}

Supported by grants from Réseau SIDA et maladies infectieuses of le Fonds de la recherche du Québec-santé (FRQ-S) to HS, VL, and NL.

\section{Author details}

${ }^{1}$ Division of Infectious Diseases, CHU Sainte-Justine, 3175 Côte Sainte-Catherine, Montreal, Quebec H3T 1C5, Canada. ${ }^{2}$ Department of Pediatrics, Faculty of Medicine, Université de Montréal, Montreal, Canada. ${ }^{3}$ Centre maternel et infantile sur le SIDA, CHU Sainte-Justine, Montreal, Canada. ${ }^{4}$ Unité de recherche clinique appliquée, CHU Sainte-Justine, Montreal, Canada. ${ }^{5}$ Division of Obstetrics and Gynecology, CHU Sainte-Justine, Montreal, Canada. ${ }^{6}$ Unité d'immunopathologie virale, Centre 
de recherche du CHU Sainte-Justine, Montreal, Canada. ${ }^{7}$ Department of Microbiology, Infectious Diseases and Immunology, Faculty of Medicine, Université de Montréal, Montreal, Canada.

Received: 7 February 2014 Accepted: 25 April 2014

Published: 5 May 2014

\section{References}

1. Mandelbrot L, Landreau-Mascaro A, Rekacewicz C, Berrebi A, Bénifla JL, Burgard M, Lachassine E, Barret B, Chaix ML, Bongain A, Ciraru-Vigneron N, Crenn-Hébert C, Delfraissy JF, Rouzioux C, Mayaux MJ, Blanche S, Agence Nationale de Recherches sur le SIDA (ANRS) 075 Study Group: LamivudineZidovudine combination for prevention of maternal-infant transmission of HIV-1. JAMA 2001, 285:2083-2093.

2. European Collaborative Study: Mother-to-child transmission of HIV infection in the era of highly active antiretroviral therapy. Clin Infect Dis 2005, 40:458-465.

3. Forbes JC, Alimenti AM, Singer J, Brophy JC, Bitnun A, Samson LM, Money DM, Lee TC, Lapointe ND, Read SE: A national review of vertical HIV transmission. AIDS 2012, 26:757-763.

4. Filteau S: The HIV-exposed, uninfected African child. Trop Med Int Health 2009, 14:276-287.

5. Marinda E, Humphrey JH, lliff PJ, Mutasa K, Nathoo KJ, Piwoz EG, Moulton LH, Salama P, Ward BJ, ZVITAMBO Study Group: Child Mortality according to maternal and infant HIV status in Zimbabwe. Pediatric Infec Dis J 2006 26:519-526.

6. Shapiro RL, Lockman S, Kim S, Smeaton L, Rahkola JT, Thior I, Wester C, Moffat C, Arimi P, Ndase P, Asmelash A, Stevens L, Montano M, Makhema J, Essex M, Janoff EN: Infant morbidity, mortality, and breast milk immunologic profiles among breast-feeding HIV-infected and uninfected women in Botswana. J Infect Dis 2007, 196:562-569.

7. Mussi-Pinhata MM, Freimanis L, Yamamoto AY, Korelitz J, Pinto JA, Cruz ML, Losso MH, Read JS: Infectious disease morbidity among young HIV-1exposed but uninfected infants in Lain America and Caribbean Countries: The National Institute of Child Health and Human Development International Site Development Initiative Perinatal Study. Pediatrics 2007, 119:e694-e704.

8. Fulforf T-A, Pierre R, Lewis K, Palmer P, Walters C, Christie CDC: Infectious Disease Morbidity and Growth Pattern of HIV Exposed Uninfected Infants in Jamaica: An Epidemiological Cohort Study. Washington D.C: AIDS; 2012. Abstract \# MOPE115.

9. Thorne C, Newell ML, Dunn D, Peckham C, Giaquinto C, Ruga E, Cozzani S, DeRossi A, Delia R, GroschWorner I, Mok J, Omenaca F, GarciaRodriguez MC, Bates I, DeJose I, Hawkins F, Zapico RM, AsensiBotet F, Otero MC, PerezTamarit D, Molina AG, Canosa C, Scherpbier H, Bohlin AB, Belfrage E, Levy J, Alimenti A, Ferrazin A, DeMaria A, Gotta C, et al: Hospitalization of children born to human immunodeficiency virus-infected women in Europe. Pediatric Infect Dis J 1997, 16:1151-1156.

10. Singh HK, Gupte N, Kinikar A, Bharadwaj R, Sastry J, Suryavanshi N, Nayak U, Tripathy S, Paranjape R, Jamkar A, Bollinger RC, Gupta A, SWEN India Study Team: High rates of all-cause and gastroenteritis-related hospitalization morbidity and mortality among HIV-exposed Indian infants. BMC Infect Dis 2011, 11:193.

11. Taha TE, Graham SM, Kumwenda NI, Broadhead RL, Hoover DR, Markakis D, van Der Hoeven L, Liomba GN, Chiphangwi JD, Miotti PG: Morbidity among human immunodeficiency virus-1 infected and uninfected African Children. Pediatrics 2000, 106:E77.

12. Epalza C, Goetghebuer T, Hainaut M, Prayez F, Barlow P, Dediste A Marchant A, Levy J: High Incidence of Group B Streptococcal Infections in HIV-Exposed Uninfected Infants. Pediatrics 2010, 126:e631-e638.

13. Karpelowsky JS, Millar AJ, van der Graaf N, van Bogerijen G, Zar HJ: Outcome of HIV-exposed uninfected children undergoing surgery. BMC Pediatr 2011, 11:69.

14. McNally LM, Jeena PM, Gajee K, Thula SA, Sturm AW, Cassol S, Tomkins AM, Coovadia HM, Goldblatt D: Effect of age, polymicrobial disease, and maternal HIV status on treatment response and cause of severe pneumonia in South African Children; a prospective descriptive study. Lancet 2007, 369:1440-1451.

15. Slogrove A, Reije B, Nadoo S, De Beer C, Ho K, Cotton M, Bettinger J, Speert $D$, Esser M, Kollmann T: HIV-exposed uninfected infants are at increased risk of severe infections in the first year of life. J Trop Pediatr 2012 58:505-508
16. Brahmbhatt H, Kigozi G, Wabwire-Mangen F, Serwadda D, Lutalo T, Nalugoda F, Sewankambo N, Kiduggavu M, Wawer M, Gray R: Mortality in HIV-infected and uninfected children of HIV-infected and uninfected mothers in rural Uganda. J Acquir Immune Defic Syndr 2006, 41:504-508.

17. Landes M, van Lettow M, Chan AK, Mayuni I, Schouten EJ, Bedell RA: Mortality and health outcomes of HIV-exposed and unexposed children in a PMTCT cohort in Malawi. PLoS One 2012, 7:e47338.

18. Heresi GP, Caceres E, Reuben J, Doyle M: Pneumocystis carinii pneumonia in infants who were exposed to human immunodeficiency virus but were not infected: an exception to the AIDS surveillance case definition. Clin Infec Dis 1997, 25:739-740.

19. Morrow BM, Hsaio NY, Zampoli M, Whitelaw A, Zar HJ: Pneumocystis pneumonia in South African children with and without human immunodeficiency virus infection in the era of highly active antiretroviral therapy. Pediatric Infect Dis J 2010, 29:535-539.

20. Slogrove AL, Cotton MF, Esser M,M: Severe infections in HIV-exposed uninfected infants; clinical evidence of immunodeficiency. J Tropical Pediatrics 2010, 56:75-81

21. Afran L, Garcia Knight M, Nduati E, Urban B, Heyderman RS, Rowland-Jones SL: HIV-exposed uninfected children: a growing population with a vulnerable immune system? Clin Exp Immunol 2013, Epub ahead of print.

22. Clerici M, Saresella M, Colombo F, Fossati S, Sala N, Bricalli D, Villa ML, Ferrante P, Dally L, Vigano' A: T-lymphocyte maturation abnormalities in uninfected newborns and children with vertical exposure to HIV. Blood 2000, 96:3866-3871.

23. Ono E, Sanots AM N d, de Menezes Succi RC, Machado DM, de Angelis DS, Salomão R, Kallás EG, de Moraes-Pinto Ml: Imbalance of naive and memory $T$ lymphocytes with sustained high cellular activation during the first year of life from uninfected children born to HIV-1 infected mothers on HAART. Braz J Med Biol 2008, 41:700-708.

24. Chougnet C, Kovacs A, Baker R, Mueller BU, Luban NL, Liewehr DJ, Steinberg $S M$, Thomas EK, Shearer GM: Influence of human immunodeficiency virusinfected mater- nal environment on development of infant inter- leukin-12 production. J Infect Dis 2000, 181:590-597.

25. Vigano A, Saresella M, Schenal M, Erba P, Piacentini L, Tornaghi R, Naddeo V, Giacomet V, Borelli M, Trabattoni D, Clerici M: Immune activation and normal levels of endogenous antivirals are seen in healthy adolescents born of HIV-infected mothers. AIDS 2007, 21:245-248.

26. Romano MF, Buffolano W, Bisogni R, Russo R, Liuzzi R, Bunders M, Newell ML, Giarrusso PC: Increased CD154 expression in uninfected infants born to HIV-positive mothers exposed to antiretroviral prophylaxis. Viral Immunol 2006, 19:363-372.

27. Miyamoto M, Pessoa SD, Ono E, Machado DM, Salomão R, Succi RC, Pahwa S, de Moraes-Pinto Ml: Lower CD4+ T-cell levels and B-cell apoptosis in vertically HIV-exposed noninfected children and adolescents. J Trop Pediatr 2010, 56:427-432.

28. Neilsen SD, Jeppesen DL, Kolte L, Clark DR, Sørensen TU, Dreves AM, Ersbøll $A K$, Ryder $L P$, Valerius NH, Nielsen JO: Impaired progenitor cell function in HIV-negative infants of HIV positive mothers results in decreased thymic output and low CD4 counts. Blood 2001, 2001(98):398-404.

29. Le Chenadec J, Mayaux MJ, Guihenneuc-Jouyaux C, Blanche S, Enquête Périnatale Française Study Group: Perinatal antiretroviral treatment and hematopoiesis in HIV-uninfected infants. AIDS 2003, 17:2053-2061.

30. Pachero SE, McIntosh K, Lu M, Mofenson LM, Diaz C, Foca M, Frederick M, Handelsman E, Hayani K, Shearer WT: Effect of perinatal antiretroviral drug exposure on hematological values in HIV-uninfected children: an analysis of the women and infants transmission study. JID 2006, 194:1089-1097.

31. Neu N, Leighty R, Adeniyi-Jones S, Diaz C, Handelsman E, Kaufman G, Paul ME, Rich K, Mofenson L, Pitt J, Women and Infants Transmission Study: Immune parameters and morbidity in hard drug and human immunodeficiency virus-exposed but uninfected infants. Pediatrics 2004, 113:1260-1266.

32. Dauby N, Goetghebuer T, Kollmann TR, Levy J, Marchant A: Uninfected but not unaffected: chronic maternal infections during pregnancy, fetal immunity, and susceptibility to postnatal infections. Lancet Infect Dis 2012, 12:330-340.

33. Pit DS, Polderman AM, Schulz-Key H, Soboslay PT: Prenatal immune priming with helminth infections: parasite-specific cellular reactivity and Th1 and Th2 cytokine responses in neonates. Allergy 2000, 55:732-739.

34. Malhotra I, Mungai P, Muchiri E, Ouma J, Sharma S, Kazura JW, King CL: Distinct Th1- and Th2-Type prenatal cytokine responses to Plasmodium falciparum erythrocyte invasion ligands. Infect Immun 2005, 73:3462-3470. 
35. Dauby N, Alonso-Vega C, Suarez E, Flores A, Hermann E, Córdova M, Tellez T, Torrico F, Truyens C, Carlier Y: Maternal infection with Trypanosoma cruzi and congenital Chagas disease induce a trend to a type 1 polarization of infant immune responses to vaccines. PLoS Negl Trop Dis 2009, 22:e571.

36. Legrand FA, Nixon DF, Loo CP, Ono E, Chapman JM, Miyamoto M, Diaz RS, Santos AM, Succi RC, Abadi J, Rosenberg MG, de Moraes-Pinto MI, Kallas EG: Strong HIV-1-specific T cell responses in HIV-1-exposed uninfected infants and neonates revealed after regulatory T cell removal. PLoS One 2006, 1:e102.

37. Rowland-Jones SL, Nixon DF, Aldhous MC, Gotch F, Ariyoshi K, Hallam N, Kroll JS, Froebel K, McMichael A: HIV-specific cytotoxic T-cell activity in an HIV-exposed but uninfected infant. Lancet 1993, 341:860-861.

38. Cheynier R, Langlade-Demoyen P, Marescot M-R, Blanche S, Blondin G, Wain-Hobson S, Griscelli C, Vilmer E, Plata F: Cytotoxic T lymphocyte responses in the peripheral blood of children born to HIV-1 infected mothers. Eur J Immunol 1992, 22:2211-2217.

39. Kuhn L, Coutsoudis A, Moodley D, Trabattoni D, Mngqundaniso N, Shearer GM, Clerici M, Coovadia HM, Stein Z: T-helper cell responses to HIVenvelope peptides in cord blood: protection against intrapartum and breast-feeding transmission. AIDS 2001, 15:1-9.

40. Moraleda C, de Deus N, Serna-Bolea C, Renom M, Quinto L, Macete E, Menendez C, Naniche D: Impact of HIV-exposure on health outcomes in HIV-negative infants born to HIV-positive mothers in Sub-Saharan Africa. J Acquir Immune Defic Syndr 2014, 66:182-189.

41. Kuhn L, Meddows-Taylor S, Gray G, Tiemessen C: Human Immunodeficiency Virus (HIV)-specific cellular immune responses in newborns exposed to HIV in utero. Clin Infect Dis 2002, 34:267-276.

42. Faye A, Pornpraset S, Mary JY, Dolcini G, Derrien M, Barré-Sinoussi F, Chaouat G, Menu E: Characterization of the main placental cytokine profiles from HIV-1 infected pregnant women treated with anti-retroviral drugs in France. Clin Exp Immunol 2007, 149:430-439.

43. Economides A, Schmid I, Anisman-Posner DJ, Plaeger S, Bryson YJ, Uittenbogaart $\mathrm{CH}$ : Apoptosis in cord blood T lymphocytes from infants of human immunodeficiency virus-infected mothers. Clin Diagn Lab Immunol 1998, 5:230-234.

44. Jones CE, Naidoo S, De Beer C, Esser M, Kampmann B, Hesseling AC Maternal HIV infection and antibody responses against vaccinepreventable diseases in uninfected infants. JAMA 2011, 305:576-584

45. Reike BA, Naidoo S, Ruck CE, Slogrove AL, de Beer C, la Grange H, Adams RC, Ho K, Smolen K, Speert DP, Cotton MF, Preiser W, Esser M, Kollmann TR: Antibody responses to vaccination among South African HIV-exposed and unexposed uninfected infants during the first two years of life. Clin Vaccine Immunol 2013, 20:33-38.

46. Bunders M, Pembrey L, Kuijpers T, Newell ML: Evidence of impact of maternal HIV infection on immunoglobulin levels in HIV-exposed uninfected children. AIDS Res Hum Retroviruses 2010, 26:967-975.

47. Sanz-Ramos M, Manno D, Kapambwe M, Ndumba I, Musonda KG, Bates M, Chibumbya J, Siame J, Monze M, Filteau S, Gompels UA: Reduced Poliovirus vaccine neutralizing antibody titres in infants with maternal HIV exposure. Vaccine 2013, 31:2042-2049.

48. Abramczuk BM, Mazzola TN, Moreno YM, Zorzeto TQ, Quintilio W, Wolf PS, Blotta MH, Morcillo AM, da Silva MT, Dos Santos Vilela MM: Impaired Humoral response to vaccines among HIV-exposed uninfected infants. Clin Vaccine Immunol 2011, 18:1406-1409.

49. Cutland CL, Schrag SJ, Zell ER, Kuwanda L, Buchmann E, Velaphi SC, Groome MJ, Adrian PV, Madhi SA, PoPS trial team: Maternal HIV infectionx and vertical transmission of pathogenic bacteria. Pediatrics 2012, 130:e581-e590.

50. Wiener JB, Kayira D, Chasela C, King CC, Ellington SR, Hosseinipour M, Jamieson DJ, Van der Horst C, Kourtis AP, BAN Study Team: Morbidity and Mortality Among HIV-1-Exposed Uninfected Infants Enrolled in the Breastfeeding, Antiretrovirals and Nutrition (BAN) Trial in Malawi. Washington D.C: XIX International AIDS Conference; 2012. Abstract no WEPE178.

doi:10.1186/1471-2334-14-236

Cite this article as: Kakkar et al:: Impact of maternal HIV-1 viremia on lymphocyte subsets among HIV-exposed uninfected infants: protective mechanism or immunodeficiency. BMC Infectious Diseases 2014 14:236.

\section{Submit your next manuscript to BioMed Central and take full advantage of:}

- Convenient online submission

- Thorough peer review

- No space constraints or color figure charges

- Immediate publication on acceptance

- Inclusion in PubMed, CAS, Scopus and Google Scholar

- Research which is freely available for redistribution 